Mediterránea Ser. Biol. (1991), n. ${ }^{0}$ 13. Pág. 5-14

\title{
BREEDING SUCCESS OF THE GOLDFINCH CARDUELIS CARDUELIS IN ORANGE PLANTATIONS: THE EFFECT OF PREDATION AND STARVATION
}

\author{
por \\ J. A. GIL-DELGADO*, M, C. CATALÁ*, and E. BARBA*
}

\section{SUMMARY}

Some aspects of the breeding ecology of the Goldfinch Carduelis carduelis were studied during fifteen years in eastern Spain. Density varied between $0-0.6$ breeding pairs per $10 \mathrm{Ha}$. Egg laying usually lasted from early March to early July. The average number of nesting attempts per pair was 3.1. (range 2-4), and no more than three successful clutches per pair were detected. The mean clutch size was 4.0 eggs in February-March, 4.5 during April-May, and 3.8 during June-July, the difference between the last two periods being significant. The eggs were incubated an average of 13.3 days, and the nestlings remained in the nests a mean of 13.9 days. Breeding success decreased significantly during the season from $80 \%$ in FebruaryMarch to $19 \%$ in June-July. No nestling starved during February-March but one third of the nestlings starved during the last two periods. Predation was highest during June-July. Each pair laying 3-4 clutches fledged an average of 6.7 (range $0-10$ ) young per year and $59 \%$ of all nests produced at least one fledgling.

Laying dates and clutch size of the Goldfinch at Sagunto fitted the general trends of starting breeding earlier and laying smaller clutches as the latitude decreases. However, the seasonal pattern of nesting failure was opposite to that described in other habitats. Probable causes are discussed.

KEY WORDS: Breeding season, Breeding success, Carduelis carduclis, Causes of nesting failure, Clutch size, Orange groves, Sagunto (East Spain).

\section{RESUMEN}

Se presentan los resultados de un estudio sobre la ecología de reproducción del jilguero Carduelis carduelis realizado en cultivos de naranjo en Sagunto (España) durante 15 años. La densidad osciló entre 0 y 6.6 parejas nidificantes por $10 \mathrm{Ha}$. El período de puesta se extiende, en general, entre primeros de marzo y primeros de Julio. Cada pareja construye una media de 3.1 (rango 2-4) nidos, aunque tres es el máximo si todos tienen éxito. El tamaño medio de puesta es de 4.0 huevos en febrero-marzo, 4.5 en abril-mayo, y 3.8 en junio-julio, siendo significativa la diferencia entre los dos últimos períodos. El período medio de incubación fue de 13.3 días, y los pollos permanecieron en el nido una media de 13.9 días. El éxito reproductor

\footnotetext{
* Departamento de Ecología. Universidad de Valencia.
} 
(producción de pollos en función del número de huevos) decrece significativamente al avanzar la estación, desde un $80 \%$ en febrero-marzo hasta un $19 \%$ en junio-julio. Durante febreromarzo no muere ningún pollo por inanición, pero la mortaliadad por esta causa afecta a un tercio de los pollos el resto de la estación. La predación es más alta durante junio-julio. Las parejas con 3-4 puestas producen una media de 6.7 (rango 0-10) pollos por año. Del $59 \%$ de los nidos vuela, al menos, un pollo.

El inicio de la estación reproductora y el tamaño de puesta del jilguero en Sagunto están de acuerdo con la tendencia de empezar la nidificación antes y reducir el tamaño de puesta al disminuir la latitud. Sin embargo, el patrón estacional de mortalidad en el nido es opuesto al descrito en otros habitats. Se discuten las posibles causas de estas diferencias.

PAlabraS Clave: Carduelis carduelis, Causas de mortalidad, Estación de nidificación, Éxito reproductor, Naranjal, Sagunto (España), Tamaño de puesta.

\section{INTRODUCTION}

The breeding ecology of the Goldfinch has received less attention than that of other finch species, although population trends, food, seed preferen$\mathrm{ce}$, and some other topics have been studied both in its original area of distribution and in areas where it has been introduced (Conder 1948, Frith 1957, Newton 1967, Sharrock 1976, Glück 1980, 1985) There are few studies on the Goldfinch in the Iberian Peninsula, and these refer to feeding, migration, distribution, and density values from habitats where the avifauna has been studied (Gil 1928, Herrera 1978, Senar and Borrás 1983, Gil-Delgado 1983, Asensio 1986).

In this paper we present the results of a fifteen year study (1975-1989) of the Goldfinch in orange groves, where it is the least common breeding cardueline finch (Gil-Delgado 1983). We show the population trend over this period, and explore the timing of the breeding season and clutch size trends. There is a broad acceptance that the beginning of the breeding season is delayed and clutch size increases with latitude (Cody 1971, Von Haartman 1971, Perrins and Birkhead 1983). Therefore, we expected a smaller average clutch size and earlier laying dates in our study area than those reported in more northern sites.

Our main interest in this study was to investigate the effect of predation during the breeding season in relation to other factors influencing nest failure. Predation is the main cause of nest failure, acting on both eggs and nestlings (Ricklefs 1969, O'Connor 1985). Newton (1978) showed that nest predation in cardueline finches declines as the season progresses, suggesting that the gradual thickening of the vegetation makes nests more difficut for predators to find. This should increase breeding success at the end of the season, while the recruitment of young into the breeding population is low early in the season (Newton 1978). However, the other two species of cardueline finch breeding in orange groves do not follow this pattern. The Serin Serinus serinus shows a decline in breeding success as the season progesses (Gil-Delgado 1981), and the Greenfinch Carduelis chloris experiences more nest failvres at the end of the breeding season (Gil-Delgado and Catalá 1989). In both species mortality by starvation is higher than by preda- 
tion at the end of the breeding season (Gil-Delgado and Gómez 1988, GilDelgado and Catala 1989). Therefore, if these patterns apply to all cardueline finches in orange groves, we could expect similar results for the Goldfinch.

Habitats created or modified by man nowadays support the most dense populations of many species of cardueline finch (Lack 1971). Large areas in the East and South of Spain are covered by orange plantations, so the information presented here is representative of the breeding ecology of the Goldfinch in this region.

\section{STUDY AREA AND METHODS}

The study area was a $16.92 \mathrm{Ha}$ plot located near Sagunto, Valencia (eastern Spain, $39^{\circ} 42^{\prime} \mathrm{N}, 0^{\circ} 15^{\prime} \mathrm{W}, 30 \mathrm{~m}$.a.s.1.), close to the shoreline of the Mediterranean Sea. Cultivated trees, mainly oranges Citrus aurantium, but also a few rows of medlars Mespilus germanica, covered the study and surrounding area. The understorey was composed of herbaceous plants (see Gil-Delgado et al. 1979). The predator species observed in the plot were reported by Gil-Delgado and Escarré (1977).

To determine the density of Goldfinches we used both the mapping method and nest searching (see Gil-Delgado 1981, 1983) each year, except in 1978 and 1979 when only the presence or absence of the species was assessed. All the trees were inspected at least once every 2-3 weeks, and the nests located were checked twice a week. All the contacts with the birds were recorded on working maps throughout the breeding season. The regular spacing of the trees allowed us to place both nests and bird contacts exactly. There was some intraseasonal variation in the number of pairs detected within the study area (Gil-Delgado unpubl. data) due to the itinerant behaviour of the Goldfinch during the breeding season (see Newton 1978); the density values reported here are the maximum recorded each year.

During the study period we located 99 Goldfinch nests, probably all that were built within the study area. The phenology of the breeding season has been drawn from the complete sample, since laying date could be estimated for all nests. Clutch size and breeding success were analyzed using a sample of 58 nests, for which have adequate data. These nests were found either before the first egg was laid or at least ten days before hatching.

Cardueline finches tend to breed in groups where each pair occupies a small area, and they can change their breeding site within a breeding season (see Newton 1978, Glück 1980). Both patterns make it dificult to determine the number of nests that a single pair builds in one breeding season, especially when working with unmarked birds. To estimate the number of nesting attempts per pair we selected those pairs that bred solitarily, and for which the presence of a singing male was continuous during the season ( $\mathrm{n}$ $=9$ ). We assumed that consecutive clutches in nearby trees belonged to the same pair (see Newton 1978). 


\section{RESULTS}

\section{Population trend}

The number of breeding pairs per year varied between 0 and 11 during the study period (density values $0-0.6$ pairs per $10 \mathrm{Ha}$., see fig. 1). For 1978 we do not know the exact number of pairs although the Goldfinch bred in the estudy area. Between 1979 and 1981 no pair bred, and from 1982 onwards the population increased. The highest numbers of breeding pairs were reached in the last two seasons.

Twenty-four pairs bred solitarily. We also detected groups with two (n $=5)$, three $(\mathrm{n}=3)$ and four $(\mathrm{n}=1)$ breeding pairs. During the period 1975-1987 there were 17 solitary pairs while four groups, comprising nine pairs, were recorded. By contrast, during the period 1988-1989, when the densities were higher, five groups, comprising 14 pairs, were detected while only seven pairs bred solitarily. The difference in nesting distribution between the two periods is significant $\left(X^{2}=4.77\right.$, d.f. $\left.=1, \mathrm{p}<0.05\right)$.

\section{Breeding time and number of clutches per pair}

Figure 2 shows the laying date of all the clutches grouped in ten-day intervals. Out of the six seasons with adequate data, in five (1977 and 1986-

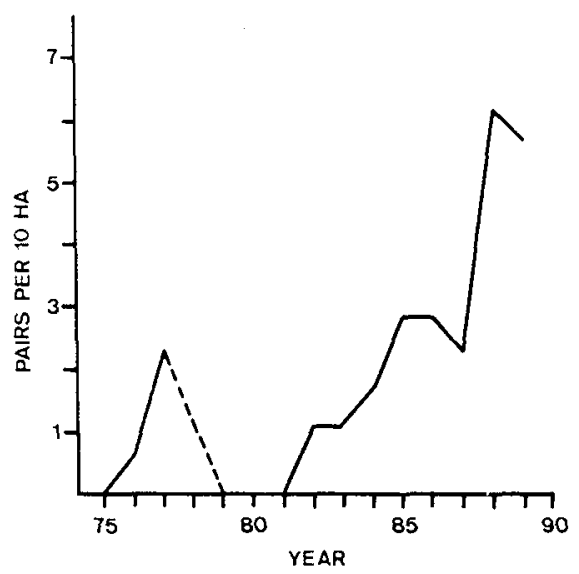

Figure 1.- Population density (breeding pairs per $10 \mathrm{Ha}$ ) during the study years. Discontinuous line is for 1978 , when the species was present but the density was not determined.

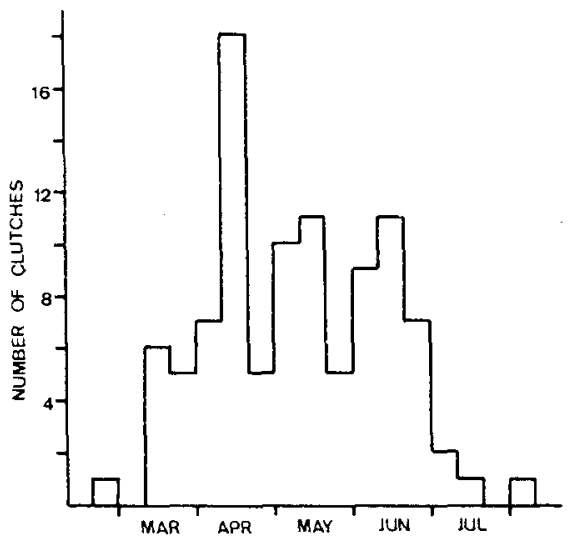

Figure 2.- Seasonal distribution of the clutches (ten day periods) in relation to their laying dates. 


\begin{tabular}{|c|c|c|c|c|c|c|c|c|c|}
\hline \multirow[b]{2}{*}{ Code } & \multicolumn{2}{|c|}{$1 \mathrm{st}$ clutch } & \multicolumn{2}{|c|}{ 2nd clutch } & \multicolumn{2}{|c|}{ 3rd clutch } & \multicolumn{2}{|c|}{ 4th clutch } & \multirow{2}{*}{$\begin{array}{c}\text { Total } \\
\text { Fledglings }\end{array}$} \\
\hline & Date & Fledglings & Date & $\overline{\text { Fledglings }}$ & Date & Fledglings & Date & Fledglings & \\
\hline $\begin{array}{c}\text { T185 } \\
9\end{array}$ & 15-III & 4 & $4-V$ & 5 & & & & & \\
\hline $\mathrm{T} 285$ & 18-III & 0 & 29-III & 0 & 20-IV & 4 & $5-\mathrm{VI}$ & 3 & 7 \\
\hline T385 & 14-IV & 5 & $22-\mathrm{V}$ & 4 & 26-VI & 0 & 10-VII & 0 & 9 \\
\hline T188 & 2-IV & 4 & $9-\mathrm{V}$ & 4 & 21-VI & 2 & & & 10 \\
\hline T288 & $11-\mathrm{IV}$ & 0 & 21-IV & 0 & $19 . \mathrm{V}$ & 0 & 9-VI & 0 & 0 \\
\hline T388 & $18-I V$ & 0 & $9-\mathrm{V}$ & 4 & & & & & 4 \\
\hline T189 & 13-III & 4 & 28-IV & 0 & $18-V$ & 1 & 23-VI & 0 & 5 \\
\hline $\mathrm{T} 289$ & $11-\mathrm{IV}$ & 0 & $5-\mathrm{V}$ & 5 & $22-\mathrm{VI}$ & 4 & & & 9 \\
\hline T389 & $22-\mathrm{IV}$ & 2 & $5-\mathrm{VI}$ & 0 & & & & & 2 \\
\hline
\end{tabular}

Table I.- Known breeding histories of nine Goldfinch pairs within a single season. Last two numbers of the pair code indicate the year. The laying date of the first egg and the number of young fledged is presented for each clutch. The total number of fledglings each pair produced is shown.

89) Goldfinches started laying by middle March and the last clutches were laid between late June and early July. However, in 1985, the first egg was laid on 26 February, and the first egg of the last clutch on 2 August.

Table I shows the breeding histories of nine pairs (see Methods for their selection criteria) in a single season. The average number of nests per pair was 3.1 (s.d. $=0.87$ ). However, this value must be considered as a minimum since the sample size is small and pairs T185, T388 and T389 could have built additional nests in other breeding sites. The laying of a fourth clutch, after three successful ones, is suspected, but we have not conclusive data and should be very rare.

\section{Clutch size}

We located 58 complete clutches, but most of them could not be ascribed to first, second, or successive clutches with certainty. Therefore, we have divided the sample according to the month in which the first egg of each clutch was laid. The single clutch from February was pooled with those from March, and the two clutches from July with those from June. The average clutch size in April (4.4 eggs, s.d. $=0.8, \mathrm{n}=15$ ) and May (4.5 eggs, s.d. $=0.7, \mathbf{n}=16)$ did not differ significantly $(\mathrm{t}=0.17$, d.f. $=29)$, so we have pooled them (table II). Average clutch size showed significant differences among the three periods $\left(\mathrm{F}_{2,55}=4.65, \mathrm{p}<0.05\right)$, the decrease between the second and the third period being significant $(t=2.90$, d.f. $=46$, $\mathrm{p}<0.01$ ). The mode describes the pattern of clutch size during the breeding season: clutches of 4 eggs were more frequent in Fébruary-March, clutches of 5 eggs in April-May, and clutches of 3 eggs in June-July. 
TABLE II

\begin{tabular}{llrrrrr}
\hline & & Clutch size & & Mean & sd & n \\
\cline { 2 - 4 } & 3 & 4 & 5 & & & \\
\hline Feb-Mar & 2 & 6 & 2 & 4.00 & 0.63 & 10 \\
Apr-May & 5 & 7 & 19 & 4.45 & 0.75 & 31 \\
Jun-Jul & 8 & 5 & 4 & 3.76 & 0.81 & 17 \\
\hline
\end{tabular}

Table II.- Seasonal variation in clutch size.

The mean incubation period was 13.3 days (s.d. $=0.63$, range $12-14$, $\mathrm{n}=10$ ). After hatching the nestlings remained in the nest a mean of 13.9 days (s.d. $=1.1$, range $12-16, \mathrm{n}=14$ ). These values were calculated only from nests visited daily during the critical periods.

\section{Breeding success}

Table III is based on the same 58 nests as for clutch size calculations. As above, three periods were considered, pooling April and May because neither hatching $\left(X^{2}=0.12\right.$, d.f. $\left.=1\right)$ nor breeding success $\left(X^{2}=0.09\right.$, d.f. $=1$ ) differed significantly. Highly significant differences in breeding success between the three periods were found $\left(X^{2}=40.36\right.$, d.f. $\left.=2, p<0.001\right)$ with a sharp decline as the season progressed.

Hatching success showed the same trend $\left(\mathrm{X}^{2}=13.1\right.$, d.f. $=2, \mathrm{p}<$ $0.01)$ though no differences in hatching success were found between the first and middle part of the season $\left(\mathrm{X}^{2}=0.54\right.$, d.f. $\left.=1\right)$. The differences in breeding success between the two periods $\left(\mathrm{X}^{2}=8.07\right.$, d.f. $\left.=1, \mathrm{p}<0.01\right)$

TABLE III

\begin{tabular}{|c|c|c|c|}
\hline & Feb-Mar & Apr-May & Jun-Jul \\
\hline Number of eggs laid & 40 & 138 & 64 \\
\hline Hatching success & 92.5 & 88.4 & 70.3 \\
\hline Breeding success & 80.0 & 54.3 & 18.7 \\
\hline Predation on eggs & 7.5 & 5.8 & 17.2 \\
\hline Predation on nestlings & 10.0 & 3.6 & 15.6 \\
\hline Total predation & 17.5 & 9.4 & 32.8 \\
\hline Nestlings starved & 0.0 & 30.4 & 35.9 \\
\hline Mortality by other causes & 2.5 & 5.8 & 12.5 \\
\hline
\end{tabular}

Table III.- Breeding success and causes of mortality of the Goldfinch in Sagunto. The values are given in percentage in relation to the number of eggs laid each period. 
were caused by the higher loss of nestlings during April-May. Differences in predation between these two periods were not significant $\left(\mathrm{X}^{2}=2.03\right.$, d.f. $=1$ ). No nestlings from clutches laid during February-March starved, whereas $34 \%$ of the nestlings hatched from eggs laid during April-May did, the differences being highly significant $\left(\mathrm{X}^{2}=15.9\right.$, d.f. $\left.=1, \mathrm{p}<0.001\right)$. In the last part of the season mortality by starvation was also high, while losses by predation increased, resulting in a very low breeding success. In each of the three periods losses by predation were similar during egg and nestling stages.

Of the 58 nests, $34(58.6 \%)$ produced at least one fledgling. Among the 24 unsuccessful nests, twelve were destroyed by predators $(20.7 \%$ of the total), and starvation affected all the nestlings in nine $(15.5 \%)$ nests; in another fourteen we found partial losses (two of them were preyed upon later). Black Rats Rattus rattus preyed on seven nests (five during incubation and two with nestlings), ants on one with nestlings, and a snake, Malpolon monspessulanus, on theree, all with nestlings. The predator of another nest was not identified, but it was probably a snake. The proportion of nests producing at least one fledgling was similar in the 58 nests included in the above analyses than in the remaining 41 nests found $\left(\mathrm{X}^{2}<0.001\right.$, d.f. $=1$, n.s.).

Results in table I suggest that Goldfinches laid a maximum of three successful clutches (e.g. T188), with four, perhaps even five, clutches being laid if some or all of them were unsuccessful. The six pairs which 3-4 clutches (table I) each reared an average of 6.7 (s.d. $=3.6$, range $0-10$ ) fledglings per year.

\section{DISCUSSION}

The number of Goldfinches breeding in the study area fluctuated markedly from year to year, but in the last years of the study there was a large increase in their numbers. We have no information from other habitats, so we cannot confirm whether the population increase was general. The Greenfinch also presents a fluctuating pattern in the orange groves, but its numbers have decreased in the last few years (Gil-Delgado and Catalá 1989).

The Goldfinch is absent during the breeding season in some natural habitats in Spain (e.g. Peris et al. 1975, Potti 1985, Obeso 1987) but, when present, it reaches densities similar to those found in the orange groves during the first part of the present study (1975-87; see e.g. Purroy 1975, Herrera 1978, Zamora and Camacho 1984). However, densities found during the last two years in Sagunto were higher than in any other habitat.

In the orange groves of Sagunto the Goldfinch usually starts laying by mid March, i.e. between the dates reported for the other two cardueline finches breeding in this habitat, viz. the Serin which begins during early March (Gil-Delgado 1981, Gil-Delgado and Gómez 1988) and the Greenfinch which lays its first clutches one month later (Gil-Delgado and Catalá 
1989). The breeding season of the Goldfinch in Sagunto starts earlier than in both Great Britain (see Newton 1978) and Germany (see Glück 1980, 1985), agreeing with the general trend of starting the breeding season earlier as the latitude decreases (e.g. Parrins and Birkhead 1983).

The average clutch size in Catalonia is 4.5 eggs $(n=20$; Senar and Borrás 1983). In comparison with our complete sample $(n=58)$ no significant difference exists $(t=1.57$, d.f. $=76)$. In Great Britain the most frequent clutches have four or five eggs and in Scandinavia five and six (Newton 1978). In Sagunto the clutch size varied between three and five eggs, but no clutch type was more frequent than the others $\left(X^{2}=2.72\right.$, d.f. $=$ 2, n.s.). Therefore, as expected, the clutch size in Sagunto seems to be smaller than reported in northerly sites. In orange groves the average clutch size first increased and then declined, as was also the case for the Greenfinch in this habitat (Gil-Delgado and Catalá 1989), as well as for other cardueline finches (see Newton 1978).

Breeding success of the Goldfinch declines as the season progresses. The Serin and the Greenfinch also experience higher mortality at the end of the breeding season (Gil-Delgado 1981, Gil-Delgado and Gómez 1988, Gil-Delgado and Catalá 1989). Therefore, in the orange groves of Sagunto all the cardueline finches have difficulties in rearing nestlings late in the breeding season. Thus, the recruitment of young into the population is low during this period, a pattern opposite to that described by Newton (1978). The evergreen nature of the orange trees, as well as their management, and the characteristics of the predators operating within this system could be the cause of this inversed pattern. In other habitats, the vegetation becomes thicker as the season progresses probably causing a lower effect of predation (Newton 1978). In the orange groves some clearing occurs during the pruning season, from mid April to early May. If the thickness of the vegetation were important in protecting the nests from predation, we would expect to find more nests destroyed during the middle part of the season rather than later as was found. On the other hand, in the Greenfinch, Gil-Delgado and Catalá (1989) did not find any seasonal differences in predation during the breeding season. Thus, in neither the Greenfinch nor the Goldfinch predation declines at the end of the season, in contrast to what Newton (1978) has reported. The three predators we found attacking Goldfinch nests either become more active (ants and snakes) or their numbers increase (Black Rat) as the season progresses. On the other hand, these predator species explore the tree from the trunk outwards, and senses other than vision must play a basic role in their prey location.

Nestling Goldfinches suffered much starvation from the middle part of the breeding season onwards. The mortality we attributed to starvation could have been caused either by an intrinsic scarcity of food in the habitat, by the hard climatic conditions of Mediterranean regions, or by a combination of the two. Scarcity of food may explain the partial losses in some nests by the death of the last hatched young (O'Connor 1978, 1979, 1985, Lundberg and Väisänen 1979). Singer and Yom-Tov (1988) related the small 
clutches of the Hose Sparrow Passer domesticus at this time to the influence of warm and dry weather on availability of food at the end of the breeding season. Similar climatic conditions occur in Sagunto from the end of May onwards. The reduction in clutch size in the final part of the breeding season could be interpreted as the prelude of the hardness ot the environmental conditions to come. However, nearly half of the nests where we detected starvation lost all the nestlings. The main cause of mortality in some of them could have been the scarcity of food, but in some nests all the nestlings died with filled crops, as reported for the Greenfinch (Gil-Delgado and Catalá 1989). Thus, this mortality must be explained by other causes, hyperthermia (e.g. Mertens 1977) being a probable one.

Newton (1978) suggests that the number of clutches in the Goldfinch varies between two and four although he doubts that more than three clutches could be successfully raised. Since the breeding season is longer in Sagunto we would expect an increase in the number of clutches per pair. Our results do not support this prediction and three successful clutches may be the maximum reared by those pairs that start breeding early, although the mode may well be two successful clutches. This pattern has its cause in the difficulties in rearing the nestlings during the last third of the breeding season. Consequently, the early beginning of breeding in this population does not give benefits relative to more northern populations. However, within the population it is advantageous to start breeding early since it allows the successful rearing of a larger number of clutches.

Summarizing, the laying date and clutch size of the Goldfinch in Sagunto fit the general latitudinal trends. On the other hand, the seasonal pattern of breeding success is opposite to that found in other populations. We do not know how the Goldfinch behaves in natural Mediterranean habitats, and therefore the pattern found in the orange groves could be either a response to the cultivated nature of the habitat studied or a more general one to be found in this region. Studies in natural habitats are needed to solve this question.

\section{ACKNOWLEDGEMENTS}

We wish to thank P. Jordano, H. Källander, G. López and R. A. Pettifor for valuable comments on an earlier draft. We are also grateful to $\mathrm{E}$. Belda, J. A. López and J. Monrós for helping in the field work 


\section{LITERATURE CITED}

ASENSIO, B., 1986. La migración en España del Jilguero (Carduelis carduelis L.) según los resultados de anillamiento. Ardeola 33: 176-183.

CODY, M. L., 1971. Ecological aspects of reproduction. In Farner, D. S. and King, J. R. (eds.) Avian biology, vol. I. pp. 461-512. Academic Press, New York.

CONDER, P. J., 1948. The breeding biology and behaviour of the continental Goldfinch Carduelis carduelis carduelis. Ibis: 90: 493-525.

FRITH, H. J., 1957. Clutch size in the Goldfinch. Emu 57: 287-288.

GIL, A., 1928. Estudios sobre la alimentación de las aves. Bol. Real Soc. Española Hist. Nat. 28: $171-194$.

GIL-DELGADO, J. A., 1981. La avifauna del naranjal valenciano. III. El Verdecillo (Serinus serinus L.). Mediterránea Ser. Biol. 5: 97-114.

-1983. Breeding bird community in orange groves. Proc. VII Int. Con. Bird Census IBCC, V Meeting EOAC, pp. 100-106.

-and CATALÁ, M. C., 1989. El Verderón Común (Carduelis chloris): población nidificante, tamaño de la puesta y éxito reproductor. Un ejemplo de estudios a largo plazo. Mediterránea Ser. Biol. 11: 121-131.

-and ESCARRÉ, A., 1977. Avifauna del naranjal valenciano. I. Datos preliminares sobre el Mirlo (Turdus merula L.). Mediterránea Ser. Biol. 2: 89-109.

-, PARDO, R., BELLOT, J. and LUCAS, I., 1979. Avifauna del naranjal valenciano. II. El gorrión común (Passer dommesticus L.). Mediterránea Ser. Biol. 3: 69-99.

GLÜCK, E., 1980. Ernährung und Nahrungsstrategie des Stieglitzes Carduelis carduelis L. Ökol. Vögel 2: 43-91.

-1985. Seed preference and energy intake of Goldfinches Carduelis carduelis in the breeding season. Ibis 127: 421-429.

HAARTMAN, L. von, 1971. Population dynamics. In Farner, D. S. and King, J.R. (eds.) Avian biology, vol. I. pp. 391-459. Academic Press, New York.

HERRERA, C. M., 1978. Evolución estacional de las comunidades de Paseriformes en dos encinares de Andalucía occidental. Ardeola 25: 143-180.

LACK, D., 1971. Ecological isolation in birds. Blackwell, Oxford.

LUNDBERG, C. and VÄISÄNEN, R. A., 1979. Selective correlation of egg size with chick mortality in the Black-headed Gull (Larus ridiibundus). Condor 81: 146-156.

MERTENS, J. A. L., 1977. Thermal conditions for successful breeding in Great Tits (Parus major L.). II. Thermal properties of nests and nestboxes and their implications for the range of temperature tolerance of Great Tit broods. Oecologia (Berl.) 28: 31-56.

NEWTON, I., 1967. The adaptive radiation and feeding ecology of some British finches. Ibis 109: 33-98.

-1978. Finches, Collins, London.

OBESO, J. R. 1987. Comunidades de Paseriformes en bosques mixtos de altitudes medias de la Sierra de Cazorla. Ardeola 34: 37-59.

O'CONNOR, R. J., 1978. Brood reduction in birds: selection for fratricide, infanticide and suicide. Anim. Behav. 26: 79-97.

-1979. Egg weights and brood reduction in the European Switf (Apus apus). Condor 81: 133-146.

-1985. The growth and development of birds. Wiley, New York.

PERIS, S., SUAREZ, F. and TELLERÍA, J. L., 1975. Estudio ornitológico del sabinar ( $J u$ niperus thurifera L.) del Maranchón (Guadalajara). Descripción de la vegetación y aplicación del método de la parcela. Ardeola 22: 3-27.

PERRINS, C. M. and BIRKHEAD, T. R., 1983. Avian ecology. Blackie, Glasgow.

POTTI, J., 1985. La sucesión de las comunidades de aves en los pinares repoblados de Pynus sylvestris del Macizo de Ayllón (Sistema Central). Ardeola 32: 253-277.

PURROY, F. J. 1975. Evolución anual de la avifauna de un bosque mixto de coníferas y frondosas en Navarra. Ardeola 21: 669-697.

RICKLEFS, R. E., 1969. An analysis of nesting mortality in birds. Smithson. Contr. Zool. 9: 1-48.

SENAR, J. C. and BORRÁS, S. A., 1983. Cadernera. In Muntaner, J., Ferrer, X. and Martínez-Vilalta, A. (eds.) Atlas dels ocells nidificants de Catalunya i Andorra. pp. 275-276. Ketres, Barcelona.

SHARROCK, J. T. R. 1976. The atlas of breeding birds in Britain and Ireland. Poyser, Calton.

SINGER, R. and YOM-TOV, Y., 1988. The breeding biology of the House Sparrow Passer domesticus in Israel. Ornis Scand. 19: 139-144.

ZAMORA, R. and CAMACHO, I, 1984. Evolución estacional de la comunidad de aves en un robledal de Sierra Nevada. Doñana, Acta Vert. 11: 129-150. 